\title{
Economics and economic methodology in a core-periphery economic world
}

\author{
Economia e metodologia econômica em um \\ mundo econômico centro-periferia
}

JOHN B. DAVIS*,***

\begin{abstract}
RESUMO: Este artigo usa uma distinção centro-periferia para caracterizar a economia contemporânea, a metodologia econômica e também a economia mundial atual. Primeiro, aplica a distinção à organização da economia contemporânea através de um exame do problema de explicar as relações e fronteiras da economia com outras disciplinas. Em segundo lugar, argumenta que a organização centro-periférica da economia é replicada numa organização similar do uso e prática da metodologia econômica contemporânea na economia. Terceiro, ela se baseia no uso do pensamento centro-periferia na própria economia com relação ao desenvolvimento desigual da economia mundial para fornecer possíveis bases para a economia e metodologia econômica sendo organizada em termos de periferia. Quarto, o artigo discute brevemente três forças potenciais de contrapeso que operam no desenvolvimento da economia contemporânea que podem funcionar contra sua organização periferia.
\end{abstract}

PALAVRAS-CHAVE: Periferia; economia e outras disciplinas; metodologia econômica; desenvolvimento desigual; especialização; modelagem formal; giro empírico.

ABSTRACT: This paper uses a core-periphery distinction to characterize contemporary economics, economic methodology, and also today's world economy. First, it applies the distinction to the organization of contemporary economics through an examination of the problem of explaining economics' relations to and boundaries with other disciplines. Second, it argues that economics' core-periphery organization is replicated in a similar organization of the use and practice of contemporary economic methodology in economics. Third, it draws on the use of the core-periphery thinking in economics itself regarding the uneven development of the world economy to provide possible foundations for economics and economic

\footnotetext{
* Marquette University, Milwaukee, Wisconsin, United States. E-mail: john.davis@marquette.edu, orcid: https://orcid.org/0000-0001-8285-5085; Submitted: 25/October/2018; Approved: 7/January/2019.

* I I am grateful to Luiz Carlos Bresser-Pereira, Sheila Dow, Zohreh Emami, Wade Hands, Bob McMaster, Jamie Morgan, and Robert Went for comments on a previous version of this paper. The paper was presented to the Portuguese Association for Political Economy October 23, 2014 and to the Amsterdam Research Group in History and Philosophy of Economics October 25, 2018. John Davis is also professor at the University of Amsterdam.
} 
methodology being organized in core-periphery terms. Fourth, the paper briefly discusses three potential countervailing forces operating on the development of contemporary economics that might work against its core-periphery organization.

KEYWORDS: Core-periphery; economics and other disciplines; economic methodology; uneven development; specialization; formal modeling; empirical turn.

JEL classification: A12; B41; B50; O20.

\section{INTRODUCTION: APPLYING THE CORE-PERIPHERY DISTINCTION TO ECONOMICS, ECONOMIC METHODOLOGY, AND THE ECONOMY}

The core-periphery distinction is employed in the economics of trade and development, geography, network theory, the study of financial systems, and applied mathematics to distinguish a dense center of activity especially important to the performance of an entire system and a more dispersed area in the system strongly influenced by the system's core and less influential in determining the system's overall performance. ${ }^{1}$ This paper's primary goal is to employ the core-periphery distinction to explain the organization of contemporary economics (as in Davis, 2008, and Boumans and Davis, 2010, pp. 136-8), and then extend this to the use and practice of contemporary economic methodology in economics. The paper also draws on core-periphery theory in development economics to make the case that the world economy possesses a core-periphery structures, in order to also argue that the core-periphery nature of economics and economic methodology can be seen as a reflection of this wider system of social-economic organization.

I do not pretend these are not large claims, and accordingly try to proceed with the paper's arguments in a conservative manner. Specifically, the strategy of the paper is to first justify applying the core-periphery distinction to contemporary economics, and then move to a core-periphery characterization of the use and practice of contemporary economic methodology on the foundation this provides - before turning to the character of current market economies in the world today. This latter part of the paper draws on uneven development thinking in the international trade, development, and finance literature, and has independent foundations from my arguments about the core-periphery nature of economics and economic methodology. The paper closes with brief discussion of three possible countervailing forc-

\footnotetext{
${ }^{1}$ These literatures are extensive and diffuse, and only selective references are provided here. In economics, Prebisch is an early important proponent of core-periphery thinking in development theory (Prebisch, 1976, 1981; cf. Bracarense, 2016). Krugman (e.g., 1991) built his increasing returns new trade theory around the distinction. In geography, see, e.g., Azaryahu (2008). Network theory is a large domain of investigation across many disciplines, including social sciences and quantitative sciences. For the former, see, e.g., Borgatti and Everett (1999), Goyal (2007), and Jackson and Wolinksky (1996). In applied mathematics, see Rombach et al. (2014). In the study of financial systems, see Goyal and Vega-Redondo (2007) and Van der Leij et al. (2016).
} 
es that may work against the core-periphery organization of economics that concern the recent development of current economics.

The point of entry for my arguments for the core-periphery nature of economics is its status as a relatively independent social science, as shown in its postwar imperialistic orientation toward other social sciences (e.g., Lazear, 2000; Mäki, 2008; Fine and Milonakis, 2009; Davis, 2016). Disciplines can only be imperialistic or expansionary towards other disciplines when they first possess a relatively independent status (and for that matter are also subject to the reverse imperialisms of other sciences, such as the influences that psychology and other disciplines have had on economics since the 1980s). Thus, I begin by discussing the methodological problem of how one can explain economics' relations to other disciplines, and use the results of this discussion to argue that economics has a core-periphery internal structure. A payoff from this discussion is that if economics is organized in a core-periphery manner, where the periphery reflects its boundaries with other sciences, then a core-periphery distinction within economic methodology may be drawn along the lines of differences in philosophy of science thinking between economics and other related disciplines. First, however, to pose the problem of economics' boundaries with other disciplines, the next two sections discuss the nature of the 'boundaries-between-disciplines' problem, gives two approaches to its solution, rejects one, and discusses what the core-periphery distinction contributes to the second.

\section{A 'DISCIPLINE DEFINITION PARADOX'}

What economics is as a discipline can be investigated in terms of its relations to other disciplines since what makes it relatively distinct and different from other disciplines helps define its scope and nature. That is, what economics is can be investigated in terms of its boundaries with related disciplines. Yet explaining the boundaries among disciplines is not a straightforward matter. Unlike geographical or spatial boundaries, which by comparison are determinate and locatable, boundaries between disciplines are conceptual and ambiguous. We can know where the boundary among Portugal and Spain is, and when we cross it. We are unsure where the boundary between economics and psychology is, as emergence of behavioral economics demonstrates, even though economics and psychology are generally regarded as two different disciplines. Thus, explaining what economics is in virtue of its boundaries with other disciplines is a potentially quite complicated task. Yet at the same time it still seems correct to say that what makes economics what it is somehow involves how it is different from other disciplines. The difficulty, then, is that the idea of conceptual boundaries is apparently both problematic and indispensable.

I call this a 'discipline definition paradox'. Its premise is that disciplines cannot be defined in a purely internal manner without reference to other related disciplines. Addressing it then requires we make sense of the idea of conceptual bound- 
aries among disciplines in order to make the boundaries idea serviceable in debates over how different disciplines are distinct and yet still related, such as is associated with explaining behavioral economics, neuroeconomics, bioeconomics, econophysics, computational economics, network economics, etc. as combinations of economics and other sciences. Doing so draws on arguments from economic methodology and our understanding of the history of economics, and aims at providing foundations for the JEL code category A12: 'Relation of Economics to Other Disciplines.'

The next section of the paper, then, compares two approaches to explaining conceptual boundaries among disciplines, rejects one approach, and then uses the other to characterize economics' structure as a discipline in core-periphery terms. The core-periphery idea can be used to explain economics' boundaries because it distinguishes and identifies what is closer to a discipline's boundaries as what lies in its periphery. That is, its periphery identifies its boundaries. Thus, the idea offers one way of explaining how boundaries are conceptual. In effect, economics' conceptual boundaries with other disciplines stem from its own internal organization, and the distinction between core and periphery differentiates among domains within the internal structure of economics that are respectively less related and more related to other disciplines.

\section{TWO APPROACHES TO EXPLAINING CONCEPTUAL BOUNDARIES AMONG DISCIPLINES}

One approach to explaining disciplinary boundaries proceeds by creating inventories of different disciplines' conceptual contents, and then argues that their comparison demonstrates that the disciplines are different. In effect, there boundaries are defined by where they do not overlap. For example, broadly speaking, economics is about market processes and psychology is about behavior and mind. Or, economics is about individual behavior and sociology is about patterns and kinds of human relationships. Then, within each of these broad characterizations there are more particular concepts or sub-concepts associated with these broad differences. For example, economics' concern with market processes also involves the idea of equilibrium, and psychology's concern with mind includes attention to both conscious and unconscious mental processes.

There are two obvious problems with this inventory approach. First, it lacks a systematic way of selecting different disciplines' concepts and sub-concepts for comparison. If two people disagree about where to start or what the main comparisons are, there is no clear way of resolving their disagreement. It does not help to say that 'standard definitions' of disciplines employ these starting points, because that presupposes in a circular way that we already know what their differences are. Second, it is not clear how even an inventory of different disciplines' contents establishes boundaries among them. Distinct inventories imply disciplines are different, but showing they are different does not tell us anything about their shared 
boundaries where they come into contact. Indeed the inventory approach is unlikely to tell us anything more about the relation between, say, economics and psychology, which have shared boundaries, than it tells us about the relation, say, between economics and organic chemistry, which don't.

However, the first weaknesses of the inventory approach - that debates about starting points lack a means of resolution - points us toward a second approach to explaining disciplinary boundaries that emphasizes a discipline's internal organization. People, of course disagree not only over what they see as fundamental starting points in a discipline, but also disagree over the sub-concepts those starting points should involve. That is, they also disagree over how disciplines are internally organized. For many economists, for example, the equilibrium concept is a key sub-concept under the idea that economics is about market processes. Yet others, such as in the institutionalist tradition, have theories of market processes that de-emphasize equilibrium, and thus a different understanding of how economics is internally organized.

Further, it seems fair to say that in the history of economics disagreements over economics' internal organization have tended to sort out into dominant views constituting the core or 'mainstream' of the discipline and less influential, non-standard views constituting periphery of the discipline. That is, economics' internal organization historically has tended to polarize ideas and approaches into orthodox or mainstream and heterodox or dissident types of views. Not all disciplines may be organized in this way. For example, psychology appears to have many competing domains of investigation, lacks an overall hierarchical organization, and while it certainly has non-standard types of views, the discipline as a whole seems different from economics in this respect.

A discipline polarized into standard or orthodox and non-standard or heterodox views, then, provides a means of explaining its boundaries with other disciplines. Core views, as orthodox, are identified with the discipline, and by default non-standard or heterodox views are seen as not identified with it, seen as not falling fully within the discipline, and are thus closer to other sciences. Economics' boundaries are then defined by what counts as non-standard or heterodox, and indeed non-standard approaches commonly draw on other disciplines' contents. Institutionalist theories of markets, for example, employ thinking from history, law, and sociology, and are accordingly not purely economic by comparison with equilibrium theories. More generally, all theories and approaches in economics with content from other disciplines fall on the boundaries of economics. In this regard, economics' orthodox-heterodox internal organization makes economics a relatively independent, insular science, where orthodox concepts and theories are 'indigenous' or arise only out of other standard economics concepts, while heterodox concepts and theories have 'alien' contents that arise out of other disciplines.

This traditional insularity, as was noted above, is the basis for postwar neoclassical economics imperialism and also for the more recent, other disciplines' reverse imperialisms towards economics. It should not come as a surprise that imperialism's defense by orthodox economists is formulated in terms of 'indigenous' 
ideas and that reverse imperialism is formulated in terms of 'alien' ones. In the case of the former, classical trade theory and the concept of comparative advantage constitute imperialism's main theoretical rationale (Lazear, 2000; cf. Davis 2016). The conceptual resources employed have economics-only origins. In the case of reverse imperialism, for example, behavioral economics, the argument that choice is guided by decision heuristics is drawn from psychological evidence, a non-indigenous or 'alien' source of ideas from the point of view of economics' core. ${ }^{2}$

Thus, I argue that economics' status as a relatively independent discipline and its boundaries with other social science disciplines is tied to its internal core-periphery/orthodox-heterodox organization. Not having that type of organization would allow economics to freely integrate other disciplinary contents, undermine its traditional hierarchical conceptual character, and cause it to more closely resemble non-insular social sciences. I put aside here the question of what such an economics would look like, or for that matter what such disciplines look like, ${ }^{3}$ and turn to the use and practice of economic methodology in contemporary economics.

\section{ECONOMIC METHODOLOGY'S CORE-PERIPHERY ORGANIZATION}

What do I mean by the 'use and practice' of economic methodology? Economic methodology, or the philosophy of science of economics, taken as a particular type of investigation and sub-field in economics, concerns how knowledge regarding the economic world is produced and justified as knowledge. That is, its chief concern is the epistemology of economics. My focus, however, concerns the sociology of economics in that I argue that the social organization of economics on a core-periphery basis adds to epistemological arguments about the nature of knowledge in the discipline a further determination as to what counts as acceptable methodological arguments in economics. That is, 'acceptability' adds another dimension and standard beyond methodology's primary focus on epistemological justification. Thus, the 'use and practice' of economic methodology refers to how economists themselves judge the relative importance of different types of methodological arguments in economics.

Economists regularly engage in this kind of methodological sorting activity. An influential recent example is Dani Rodrik's discussion of two approaches to economic modelling: vertical and horizontal (Rodrik, 2015). The vertical approach aims to get the right explanatory model that applies to all its applications, and

\footnotetext{
${ }^{2}$ In contrast, the standard axiomatic foundations for rational choice are indigenous in the sense that their logic works to guarantee down-sloping demand and scarcity-based behavior, central concerns of economics.

${ }^{3}$ There are different ways of characterizing forms of investigation that draw on many disciplines: interdisciplinary, multi-disciplinarity, cross-disciplinarity, etc. See Davis (2018) for a transdisciplinary characterization of economics and ethics as such a field.
} 
problems of empirical fit then require that the model be continually adjusted and re-specified until that is achieved. The horizontal approach, which Rodrik favors, and which he believes most economists now favor, aims to find the right model for the particular application at hand, so that selecting a model is not a matter of further deepening one basic model but a matter of seeing models as a family of representations of similar but differing applications, each model tailored to how the circumstances of those applications differ. I say this is a 'use and practice' question because there is arguably nothing in Rodrik's argument that challenges or adds to what economic methodologists believe is important about how knowledge is produced and justified. That is, Rodrik pretty much presupposes standard economic methodology regarding the role of evidence, thinking about what models are, abstraction, etc. ${ }^{4}$ What Rodrik is engaged in, then, is complementary to what economic methodologists engage in, but is important in that it tells us something additional about economic methodology in terms of how it is employed in contemporary economics.

In particular, his arguments, and others made by practitioner economists, tell us that the methodological landscape in economics can be differentiated according to prevailing views about the nature of economics. Of course, there could be many competing views in this regard, but the argument in the last section is that economics can be differentiated in terms of an orthodox/mainstream and heterodox/ non-mainstream divide, so it is reasonable to expect that practitioner economists' views regarding the use and practice of economic methodology would replicate this divide. Indeed, Rodrik's book seems to have been influential because his position regarding modelling is influential in economics. This is not to say there is no debate among practitioner economists over the use and practice of economic methodology. Rather it is to say that those debates will tend to break down into two domains: those occurring within orthodox/mainstream economics and those occurring within heterodox/non-mainstream economics. Further, it is to say that there will be little intersection between these two sets of debates, such that issues economic methodologists might like to address that transcend this division will not be open to discussion across the profession. ${ }^{5}$

An early example of this argument that thinking about economic methodology falls into two domains in economics was advanced by Sheila Dow, a monetary economist and economic methodologist. In her review of methodology in macroeconomics, she distinguishes between two traditions in methodological thinking between which there is little communication: a Cartesian/Euclidian conception associated with orthodox macroeconomics and what she terms an open systems conception associated with traditional Keynesian and post-Keynesian macroeconomics (Dow, 1985). This division is developed more extensively in her later dis-

\footnotetext{
${ }^{4}$ See in this regard the 2018 Journal of Economic Methodology issue devoted to Rodrik's book.

${ }^{5} \mathrm{An}$ interesting question, then, is how are we to judge the issues that concern economic methodologists that ignore this divide. Alternatively, how are we to judge a practice that does so?
} 
cussion of economic methodology, in which she traces methodological differences between mainstream and heterodox economics to differences in ontological commitments, a fundamental divide regarding the relationship between facts and values in economics, deep disagreement over the nature and definition of economics, and their respective stances towards pluralism in economics (Dow, 2002).

A further example of this argument comes from Luiz Carlos Bresser-Pereira, a macroeconomist, specifically a developmental macroeconomist concerned with the relationship between macroeconomics and economic development, who emphasizes "the failure of the neoclassical tradition and of the liberal orthodoxy in promoting development with stability" (Bresser-Pereira, 2009; Bresser-Pereira, Oreiro, and Marconi, 2015, p. xviii). Bresser-Pereira divides methodology arguments in economics into two domains: a highly mathematical, hypothetical-deductive method currently associated with 'the hard core' of economics and neoclassical theory and a more open systems, historical (or empirical)-deductive method associated with classical and Keynesian macroeconomics (Bresser-Pereira, 2009). ${ }^{6}$ Bresser-Pereira argues that the 'real core' of economics rests with the latter, not the former, and that changing this state of affairs depends on reversing which type of methodology takes precedence in macroeconomics (2009, pp. 518ff).

However, that there are broadly two different domains of thinking about the use and practice of economic methodology in economics does not tell us how this divide actually functions in core-periphery terms. The core-periphery distinction used by multiple investigators in different disciplines treats the core in a core-periphery organization as determinative of the whole of the system in question. This effectively makes the divide between core and periphery hierarchical in that, first, what lies in the core dominates what lies in the periphery, and second, what lies in the core determines the overall behavior of the whole, largely irrespective of what goes on in the periphery. Applying this to the use and practice of economic methodology in economics implies that the use and practice of economic methodology in orthodox/mainstream economics both drives thinking in economics about economic methodology as a whole and additionally casts the use and practice of economic methodology in heterodox/non-mainstream economics in a negative light. Thus, for example, Rodrik's arguments are influential in economics, but not the arguments that heterodox economists would make.

The mechanism, then, by which this occurs, as argued in the last section, is the identification of economics as a discipline with its core and the concomitant dismissal of its periphery as somehow not fully economics. In the internal organization approach to explaining economics' boundaries with other disciplines, those boundaries are defined in terms of what falls furthest from a core of thinking, which is accordingly defined in an insular way in terms of 'indigenous' categories and concepts that minimize other disciplinary associations.

Consequently, a review of the different kinds of methodology concepts and

\footnotetext{
${ }^{6}$ He later extends his analysis to three types of approaches in Bresser-Pereira (2018).
} 
ideas in current economics should exhibit a polarity regarding what is acceptable and unacceptable in the discipline as determined by orthodox/mainstream economics. Debates still occur over types of concepts and ideas respectively within the core and within the periphery, but these debates are segregated and presuppose the main divide, whether explicitly or implicitly. Thus, consider the following opposed, hierarchical pairs.

\section{i. Quantitative versus qualitative reasoning}

First, one of the most apparent, as noted by many, is the divide between quantitative or mathematical and qualitative reasoning. As Roy Weintraub (2002) persuasively demonstrates, the history of economics from before the war to the present is a history of economics being increasingly shaped by mathematical representation to the point that this is now essentially its exclusive form in the most influential journal outlets. The other side of this history is the continual demotion of most forms of qualitative argument and economics' expression in natural language, often with the implication that this is a 'pre-scientific' mode of expression and thus not at a high level of science.

Note the dilemma this imposes on heterodox/non-standard economics, whose starting points are often disagreements about fundamental economic concepts and orthodox/mainstream starting points. If these disagreements are discussed, this entails qualitative discussion, which immediately renders them suspect. Alternatively, if they these disagreements are simply set aside and qualitative discussion avoided, the incentive is to mathematically model the argument to count as respectably scientific. Having a dilemma of this sort imposed on one's scientific work, I suggest, is one manifestation of work done in the periphery of a discipline. Conversely, orthodox/mainstream in the core of a discipline is professionally essentially dilemma-free in this regard, at least from a use and practice perspective.

\section{ii. Basis of assumptions}

Second, consider the more subtle methodological issue of the nature of assumptions in economic reasoning. Of course, there is considerable debate about what particular substantive assumptions orthodox/mainstream and heterodox/nonmainstream economics each make. That is not the issue from a methodological perspective. Rather from that perspective the issue is the basis on which assumptions are made, or what sort of grounds they rely on, and here the divide between the two is clear: orthodox/mainstream generates the assumptions it makes in an abstract, axiomatic way and heterodox/non-mainstream economics generally formulates assumptions that reflect historical context.

In mainstream economics, the definition of individuals is fundamental. Individuals are defined in terms of a set of abstract assumptions about preferences completeness, transitivity, and (especially) context independence or independence of irrelevant alternatives - that are universal and ahistorical in nature. This Carte- 
sian, rationalist approach to establishing the assumptions on which economic theory is constructed contrasts clearly with the heterodox view that assumptions in economics need to have an historical basis. Fred Lee puts this as follows:

heterodox economics is a historical science of the social provisioning process $[. .$.$] The heterodox explanation involves human agency embe-$ dded in cultural context and social processes in historical time affecting resources, consumption patterns, production and reproduction, and the meaning (or ideology) of the market, state and non-market/state activities engaged in social provisioning. (Lee, 2012, p. 340)

Geoffrey Hodgson thus emphasizes that assumptions in economics need to be historically specific. We must "first acknowledge[s] that there are different types ofsocio-economic system, in historical time and geographic space. The problem ofhistorical specificity addresses the limits of explanatory unification insocial science: substantially different socio-economic phenomena may requiretheories that are in some respects different" (Hodgson, 2001, p. 23).

The consequences of this divide for heterodox economics are essentially the same as in the case of the quantitative/qualitative divide. Genuine science is identified with the abstract, timeless Cartesian approach, so that historically-grounded economics is given the appearance of being poor science. As a result, any given assumption based on historical experience can always be criticized as failing to capture essential features of the situation and in need to being reformulated and reduced to those features. That is, the core-periphery organization of the use and practice of economic methodology in economics always works in an asymmetric way to promote one set of standards and demote the other.

\section{iii. Positivism}

Third, since the emergence of ordinal utility theory and the abandonment of cardinal utility theory especially under the influence of Lionel Robbins (1932), and as enshrined as a core doctrine of economics by Milton Friedman (1953), neoclassical and mainstream economists have insisted that economics is a value-free, positive science. A corollary of this view is the assumption that economic propositions can always be formulated in a value-free way, so that any economics that fails to do this and incorporates values in its assumptions is characterized as unscientific. Yet clearly the standard ordinalist framework and its associated Pareto recommendations make value judgments. ${ }^{7}$ As a consequence, certain values are silently embedded in standard economics, while all others are rejected.

Heterodox economists hold many different views regarding which values op-

\footnotetext{
${ }^{7}$ In Davis (2015), four such value judgments are: (1) Pareto judgments require that all individuals' preferences have the same weight in terms of preference satisfaction irrespective of their many other social characteristics; (2) distributional issues regarding the distribution of preference satisfaction are
} 
erate and should operate in economics. This diversity in views reinforces the mainstream position that any economics that employs values must be unscientific in that debate over value assumptions prevents building economics on the ideal of certainty based solely on value-neutral facts and empirical evidence. Thus ultimately, nonstandard economics is seen as simply a collection of opinions lacking adequate grounding, and non-standard, heterodox economists' examination of the roles values play in economics simply shows that they do not understand the requirements of good science.

\section{iv. Pluralism as a value in economics}

A fourth, opposed, hierarchical pair of methodological commitments has a more sociological basis in that it concerns established social attitudes in economics towards innovation and diversity in research and teaching, that is, the state of pluralism as a value in economics. Disciplines have cultures just as do other forms of social organization, one aspect of which are norms regarding the expected and allowable space in which individuals engage in their disciplinary activities.

On the one hand, pluralism as a norm has a natural place in heterodox economics, which is made up of a number of different approaches: post-Keynesian economics, Marxist economics, feminist economics, institutionalist economics, social economics, stratification economics, ecological economics, 'old' behavioral economics, and a variety of different political economic approaches, each reflecting the investigation of different dimensions of the economy.

On the other hand, since the early twentieth century orthodox economics has been dominated by a single approach, neoclassical economics, whose principle assumptions (methodological individualism, static equilibrium, marginalism, the scarcity principle, value neutrality, Pareto efficiency, and perfect competition) act as a unifying nexus for newer research programs in the mainstream such as game theory, new institutionalist economics, cliometrics, law and economics, 'new' behavioral economics, and much of experimental economics. That is, while there is greater diversity within orthodoxy since 1950, that diversity is still seen by most mainstream economists as an elaboration and continuation of a single understanding of what economic science involves.

For orthodoxy, then, the idea of pluralism within science is irrelevant to economics. It is as if one were to argue than non-science should be given equal attention as given to science. Heterodox economics from this perspective falls outside economic science, mixes into economics concepts and ideas that belong to other disciplines, and consequently cannot belong to the core of economics.

\section{v. The methodological divide in economics}

completely set aside; (3) Pareto efficiency judgments ignore the content of preferences; (4) the Pareto principle provides a specific welfare conception of well-being. 
It is not the case, then, that methodological reasoning is absent from economics. When we emphasize its use and practice, it is typically implicit, and takes the form of selective appropriation of methodological ideas according to whether practitioners occupy the core or the periphery of the discipline. That core-periphery organization produces a hierarchical ordering of methodological concepts and principles, promoting some and demoting others. The means by which this is accomplished is whether a set of methodological concepts is associated with what counts as science in orthodox terms in the discipline. Purely philosophical arguments over the nature of methodological reasoning in economics investigate substantive issues in regard to the nature of economic explanation, but they rarely are formulated in terms of the use and practices of the discipline, and consequently tend to remain the exclusive concern of specialists in a relatively neglected sub-discipline of the field.

\section{UNEVEN DEVELOPMENT: THE CORE-PERIPHERY ORGANIZATION OF THE WORLD ECONOMY}

In this section, I first outline why the world economy has been argued to have a core-periphery structure, principally as reflected in the differences between developed and developing countries, and then make a case for saying how this could have influenced the way in which economics and economic methodology have developed. Essentially, I argue that in a core-periphery world, development has ceased to be perceived to be a significant concern in the developed world, where economists have also been especially influential in the development of economics, and this has reduced interest in how the organization of society affects economic development. Economics in developed countries has consequently lost its earlier identity as political economy, and the ideas and concepts associated with that vision have moved to the periphery of a discipline with a core purified of those associations.

The principle reason, then, for saying that world economy exhibits a core-periphery structure is the uneven development of the developed and developing world, as evidenced, in particular, in the persistent differences between their real per capita incomes and the lack of evidence that those incomes are converging. Indeed,

Divergence in relative productivity levels and living standards is the dominant feature of modern economic history. In the last century, incomes in the "less developed" [...] countries have fallen far behind those in the "developed" countries, both proportionately and absolutely. I estimate that from 1870 to 1990 the ratio of per capita incomes between the richest and poorest countries increased by roughly a factor of five [...] This divergence is the result of the very different patterns in the long-run economic performance of the two sets of countries. (Pritchett, 1997, p. 3) 
That is, rather than convergence, what we see is increasing divergence between most developing and developed countries since the end of the nineteenth century. ${ }^{8}$

One early explanation for this divergence was advanced by Raúl Prebisch and Hans Singer in the form of the Prebisch-Singer hypothesis, which says that the prices of primary commodities decline over time relative the prices of manufactured goods, leaving producers of the former, particularly developing nations, at a long run disadvantage in economic development. ${ }^{9}$ If we explain capital accumulation and higher living standards as resulting from economies' increasing reliance on manufacturing, then over time more industrialized economies are likely to sustain and perhaps increase their advantages over less industrialized economies.

Postwar developing country economists and policy-makers, especially in Latin America, accordingly argued that countries needed to take active steps to shift the balance in their economies out of primary commodities production toward manufacturing. This required a political commitment to adjusting economic development to social goals, which meant that economics needed to be seen as a discipline fully embedded in social science, namely, as political economy. ${ }^{10}$

In contrast, although economics in the postwar developed economies was understood as political economy from the time of Adam Smith's investigation of the causes of national wealth when those economies were concerned with problems of economic development, these problems no longer preoccupy economists in developed countries, and so economics there has shed its associations with other social sciences.

No doubt it is an illusion that developed economies do not face development challenges. That illusion is sustained by the core-periphery nature of the world economy, which makes developed countries appear by comparison to have succeeded in economic development. Thus, the economics of development is a comparatively minor field in economics research in developed economies, where research is dominated by relatively technical questions concerning how developed economies' markets function. These questions are formulated primarily in terms of ideas and concepts that are purely economic in the sense of arising out of other economic ideas and concepts, and thus largely lack reference to ideas and concepts derived from other social sciences. In short, the core of economics is free of such associations, while the periphery of economics still functions broadly as political economy. Only when serious crises beset developed economies, such as the interwar worldwide depression that led to Keynesianism and the more recent Great Finan-

\footnotetext{
${ }^{8}$ I say 'most' developing countries because the East Asian countries are an exception. Also, the major oil exporting countries might count as exceptions, though, to be clear, their GDP growth generally does not reflect economic development.

${ }^{9}$ For evidence of this see, Ocampo and Parra (2004) and Harvey et al. (2010).

${ }^{10}$ Contemporary arguments regarding how developing countries should address uneven development go substantially beyond dealing with the primary commodities trap. See the 'new developmentalism' literature that focuses on exchange rates and problems of finance and investment (Bresser-Pereira et al., 2015).
} 
cial Crisis that turned attention to financial markets, do political economic ideas re-appear in economics, only to subside again when the crisis subsides.

Thus I argue that the core-periphery nature of economics and economic methodology have a basis in the core-periphery organization of the world economy. To be clear, my argument is not a naïve reductionist one that claims the latter causes the former. As the following section argues, there are reasons to think that the development of economics and economic methodology might disconnect from world economic development. Rather, I have only argued that core-periphery nature of economics and economic methodology is functional to their current development in a world economy organized in this way. Nor do I say conspiracies are involved. Economists in the developed and developing worlds simply see themselves as faced with different types of problems, and the consequence of this is an institutionalized dual development of attitudes toward political economy in economics today.

\section{THREE COUNTERVAILING TENDENCIES TO A CONTINUING CORE-PERIPHERY DEVELOPMENT OF ECONOMICS AND ECONOMIC METHODOLOGY}

In this section I briefly review why economics and economic methodology might not continue to develop in a core-periphery manner in the future and could disconnect from the current path of world economic development. These countervailing tendencies are a product of forces operating on economics' development as a discipline, and in part need to be explained in terms of the sociology of the discipline. One concerns a force operating on economics and science in general; two concern patterns of development in the practice of economics research.

\section{i. Specialization in research}

The force operating on economics and science in general is increased specialization in research (Davis, 2019). Across science, researchers are expected to develop new avenues of investigation that go beyond existing scientific knowledge. That is, new research builds on past research, but it also departs from it, so the body of existing research in a discipline is not only continually expanding but is also continually becoming more diversified. Young sciences are defined in terms of a limited number of guiding assumptions and principles, but as they develop exceptions and emendations are made that limit the scope of those assumptions and principles, allow for new assumptions and principles, and produce a more complex view of what the discipline concerns. ${ }^{11}$ Consequently, over time it becomes increasingly difficult to say what unifies a discipline.

\footnotetext{
${ }^{11}$ For example, the relationship between recently emergent experimental economics and economics is still unclear and much debated (cf. Svorenčík and Maas, 2016).
} 
Further, I argued above that sciences have boundaries that are instrumental to their definition as separate bodies of research. Thus, should new research extend beyond those boundaries, then their definitions as separate sciences become less clear. In addition, should new core research in a discipline with a strong core-periphery structure extend to concerns traditionally investigated in its periphery, this would make the core-periphery nature of economics less clear. Take as an example research on the ultimatum game. The core theory prediction in the game is that people act in a self-interested way, meaning they accept the smallest possible offer rather than get nothing. Empirical research nonetheless demonstrates that people often reject minimum offers, and thus have more complicated motivations, possibly altruistic or fairness-driven. At the same time, it has long been argued in heterodox economics research that people's motivations are not strictly self-regarding. Thus, this type of research initiative in economics potentially challenges economics' core-periphery structure. To be clear, I do not say that specialization in economics research is certain to produce this outcome; only that specialization in research acts as a wildcard in a discipline's development and potentially works as countervailing tendency to existing structure and organization.

\section{ii. Modelling as a dominant practice in economics research}

One of the most noticeable changes in recent economics in regard to the way that research is practiced involves the emergence and dominance of formal modeling. In the past, economics models constituted an intermediate step between theorization and empirical investigation of theories. One needed a particular model representation of a theory in order to test the theory from which it was derived. Yet mainstream economists have largely given up the first step in this chain, and now build their research almost entirely around their models. ${ }^{12}$ Many mainstream economists would still refer to standard core economics beliefs as the theoretical basis for their models, but this is increasingly done informally and is treated in only a cursory way in their publications. Indeed, how models relate to underlying theories is not a simple matter, and accordingly many mainstream economists appear to prefer to let their models stand on their own, and focus on laying out the details of the model.

However, this move towards a more formal economics potentially has consequences for economics' theoretical commitments. If they are no longer explained and defended explicitly, and if their role in modeling is left out of the development of economists' models, then the commitments of standard theory become less clear and exercise a weaker effect on economics research. This in turn makes the dividing lines between core and periphery research less clear, and tends to remove insistence on those lines from debate about the nature of economics and its direction of development.

\footnotetext{
${ }^{12}$ See Rodrik's 2015 book as evidence for this conclusion.
} 
Add to this that modeling is increasingly practiced by non-standard and heterodox economists as well, since this is central to economists' professional training irrespective of their research orientations. On the one hand, then, this further reduces the apparent divide between orthodox and heterodox economics research. On the other hand, this may generate an asymmetry in the motivations of orthodox and heterodox economists since the latter tend to be strongly motivated by non-standard theory beliefs while the former, confident that their beliefs are standard, may be less motivated in this regard. Overall, then, it seems that the development of modeling as the main form of research practice may work against economics' core-periphery structure.

\section{iii. Economics as an increasingly empirical science}

The 'empirical turn' in recent economics has been noted by many (e.g., Hamermesh, 2013; Angrist et al., 2017). It surely is a positive development that economics subjects its propositions to testing. Yet there is also the possibility that this development means that economics is becoming data-driven and atheoretical. Indeed increasing data availability associated with new computing methods and the development of the internet likely create incentives in economics research to emphasize empirical results. Rodrik suggests that a horizontal conception of the modeling is displacing the more traditional vertical conception because economists have come to think that the contexts to which models apply differ significantly from one to the next. An alternative explanation for the rise of horizontal modeling is that data sets on which economists rely are particular to disparate institutional collection processes, so that increases in data availability go hand-in-hand with increasingly dispersed empirical results. Horizontal modeling would then be just a response to changes in the nature of data availability.

The possible consequences of this development, then, are essentially the same as discussed above in connection with the rise of the practice of modeling. If economics is becoming increasingly atheoretical, then what standard theory involves becomes less clear and likely exercises a weaker effect on economics research, thereby making the line between core and periphery in economics less clear. Thus, not only do the two developments in economics practice, modeling and the empirical turn, appear to reinforce each other in terms of their effects on the structure of economics, but they arguably are also framed by increasing specialization in research in economics.

\section{CONCLUDING SUMMARY}

In this final concluding section, then, I briefly summarize the paper's three main conclusions. Regarding the first, the paper's entry point is economics' relations to other disciplines. My position is that to understand the scope and nature of contemporary economics, one needs to understand its historically insular character and way 
in which it maintains boundaries with other related disciplines. The paper's first conclusion, then, is that economics' boundaries can be explained in terms of its internal organization, where that involves a core-periphery structure that distinguishes an orthodox core of economics from a heterodox periphery of economics. That orthodox core is made up of concepts and ideas that avoid reference to other social science disciplines, or that are 'indigenous' to economics. In contrast, the heterodox periphery is made up of standard economics concepts and ideas but also 'alien' concepts and ideas shared with other social science disciplines. In the postwar period, this divide has been persistent and enduring in that mainstream economists actively defend economics' independence or insularity, as reflected in general support for economics imperialism and resistance to reverse imperialisms.

The paper's second main conclusion concerns the core-periphery nature of economic methodology. Economic methodologists examine the epistemological credentials of explanations in economics, but my concern has been the use and practice of economic methodology on the part of practitioner economists, which is rather a matter of the sociology of economics. Economists are rarely concerned with what concerns economic methodologists, but consciously and unconsciously make selective methodological commitments in their research. The argument of the paper, then, is that which methodological ideas and concepts get used in economics research depend on whether a researcher in engaged in core or periphery research. In the fourth section, I identified four opposed pairs of methodology ideas and concepts, all of which, depending on their application, are per se reasonable strategies according to economic methodologists, but whose selective use serves as markers for whether economics research is orthodox or heterodox. Thus a coreperiphery division over the use and practice of economic methodology reflects the core-periphery organization of economics as a whole.

The paper's third main conclusion concerns what might underlie the first two conclusions. The argument advanced in he fifth section is that the core-periphery structure of the world economy, as captured by its pattern of uneven development and the different social and economic prospects of developed and developing countries, has particularly influenced the nature of economics in developed countries. That is, most economists there believe (mistakenly!) that problems of development only concern developing countries. I argue that a development perspective on economics is a political economic one, as prevailed in today's developed economies when they were yesterday's developing economies, so economists' belief in these countries that development is no longer a significant issue has narrowed economics from its former political economy identity, at least for mainstream orthodox economists. Heterodox economists in the periphery of economics, whatever their world location, retain a political economy understanding of economics, and are interested in making use of other social science disciplines for the investigation and explanation of development issues in developed and developing economies. Thus, the nature of the world economy plays a role in influencing the core-periphery nature of economics and economic methodology. I note also that the question of why political economy was replaced by economics in developed economies remains a 
contentious and unresolved issue for historians of economics. The argument advanced here is a new contribution to that debate.

However, if the nature of the world economy has played a role in influencing the core-periphery nature of economics and economic methodology, the paper does not argue that it fully determines it in a reductionist way. I assume that there is a disconnect between how the world economy develops and how economics and economic methodology develop, and accordingly the previous section of the paper discusses three countervailing tendencies to economics' continued development as a core-periphery discipline. My view is that both the economy and economics representation of it interact and each influences the other. So the future is open in terms of whether both will continue to exhibit their current core-periphery nature, or a new, less hierarchical economics open to other disciplines will develop in the future.

\section{REFERENCES}

Angrist Joshua, Pierre Azoulay, Glenn Ellison, Ryan Hill, and Susan Feng (2017) "Economic Research Evolves: Fields and Styles," American Economic Review 107(5): 293-297.

Azaryahu, Maoz(2008)“Tel Aviv: center, periphery and the cultural geographies of an aspiring metropolis,"Social \& Cultural Geography, 9: 3, 303-318.

Borgatti, Stephen P. and Martin G. Everett (1999) "Models of Core/Periphery Structures," Social Networks 21: 375-395.

Bracarense, Natalia (2016) "Complexities of Core-Periphery Relation: an Analysis of the Late Raul Prebisch," (November 16), The Center for the History of Political Economy Working Paper Series No. 2016-34. Available at SSRN:https://ssrn.com/abstract=2870709orhttp://dx.doi. org/10.2139/ssrn.2870709

Bresser-Pereira, Luiz Carlos (2018) “Historical models and economic syllogisms”. Journal of Economic Methodology 25: 1, 68-82.

Bresser-Pereira, Luiz Carlos (2009) “The Two Methods and the Hard Core of Economics," Journal of Post Keynesian Economics 31: 493-522.

Bresser-Pereira, Luiz Carlos, José Luís Oreiro, and Nelson Marconi (2015) Developmental Macroeconomics: New Developmentalism as a Growth Strategy, London: Routledge.

Boumans, Marcel and John Davis (2010) Economic Methodology: Understanding Economics as a Science, Basingstoke, UK: Palgrave, second edition, 2015.

Davis, John (2019) “Specialization, Fragmentation, and Pluralism in Economics," European Journal of the History of Economic Thought 26: 2.

Davis, John (2018) "Comment on White on the Relationship between Economics and Ethics," The Annals of the Fondazione Luigi Einaudi. An Interdisciplinary Journal of Economics, History and Political Science 52 (2).

Davis, John (2016) “Economics Imperialism versus Multidisciplinarity," History of Economic Ideas 24: 3: 77-94.

Davis, John (2015) “Economists' Odd Stand on the Positive-Normative Distinction: A Behavioral Economics View," Oxford University Press Handbook on Professional Economic Ethics: Views from the Economics Profession and Beyond, G. DeMartino and D. McCloskey, eds., Oxford: Oxford University Press: 200-218.

Davis, John (2008) “The turn in recent economics and return of orthodoxy," Cambridge Journal of Economics 32 (May): 349-366.

Dow, Sheila (2002) Economic Methodology: An Inquiry, Oxford: Oxford University Press. 
Dow, Sheila (1985) The Methodology of Macroeconomic Thought: A Conceptual Analysis, Cheltenham: Elgar; second edition, 1996.

Fine, Ben and Dimitris Milonakis (2009) From Economics Imperialism to Freakonomics: The Shifting Boundaries between Economics and Other Social Sciences, London: Routledge.

Milton Friedman (1953) "The Methodology ofPositive Economics," in Essays In Positive Economics, Chicago: Univ. of Chicago Press: 3-43.

Goyal, Sanjeev (2007) Connections: An Introduction to the Economics of Networks, Princeton, NJ: Princeton University Press.

Goyal, Sanjeev, FernandoVega-Redondo (2007) “Structural holes in social network," Journal of Economic Theory 137 (1), 460-492.

Hamermesh, Daniel (2013)“Six Decades of Top Economics Publishing: Who and How?”Journal of Economic Literature 51 (1): 162-72.

Harvey, David, Neil Kellard, Jakob Madsen, and Mark Wohar (2010) “The Prebisch-Singer Hypothesis: Four Centuries of Evidence," Review of Economics and Statistics 92 (2): 367-377.

Hodgson, Geoffrey (2001)How Economics Forgot History: The Problem of Historical Specificity in Social Science. London and New York: Routledge.

Jackson, Matthew, Asher Wolinsky (1996) "A strategic model of social and economic networks," Journal of Economic Theory 71 (1): 44-74.

Krugman, Paul (1991) "Increasing returns and economic geography," Journal of Political Economy 99: 483-499.

Lazear, Edward (2000) "Economic Imperialism," Quarterly Journal of Economics 115 (1): 99-146.

Lee, Fred (2012) "Heterodox Economics and Its Critics," Review of Political Economy 24 (2):337-351.

Mäki, Uskali (2008) "Economics Imperialism: Concept and Constraints," Philosophy of the Social Sciences, 9 (3), September 2009, 351-380.

Ocampo, José Antonio and María Angela Parra (2004)The Terms of Trade for Commodities in the Twentieth Century, International Trade0402006, University Library of Munich, Germany.

Prebisch, Raúl (1976) “A Critique of Peripheral Capitalism.” Cepal Review 1.

Prebisch, Raúl (1981) "The Latin American Periphery in the Global System of Capitalism." Cepal Review 13: 143-50.

Pritchett, Lant (1997) “Divergence, Big Time,” Journal of Economic Perspectives 11 (3): 3-17.

Robbins, Lionel. (1932) An Essay on the Nature and Significance of Economic Science, 2nd ed. London: Macmillan, 1935.

Rodrik, Dani (2015) Economics Rules: The Rights and Wrongs of the Dismal Science, New York: Norton.

Rombach, M. Puck, Mason Porter, James Fowler, and Peter Mucha (2014) "Core-Periphery Structure in Networks," SIAM Journal of Applied Mathematics 74: 167-190.

Svorenčík, Andrej and Harro Maas, eds. (2016) The making of experimental economics: Witness seminar on the emergence of a field, Heidelberg, Springer.

Van der Leij, Marco and in 't Veld, Daan and Hommes, Cars H., (2016) "The Formation of a Core-Periphery Structure in Heterogeneous Financial Networks," (November 4). De Nederlandsche Bank Working Paper No. 528. Available at SSRN:https://ssrn.com/abstract=2865666orhttp:// dx.doi.org/10.2139/ssrn.2865666

Weintraub, Roy (2002) How Economics Became a Mathematical Science, Durham, NC: Duke University Press. 